(C) The Author(s), 2021. Published by Cambridge University Press for the Arizona Board of Regents on behalf of the University of Arizona. This is an Open Access article, distributed under the terms of the Creative Commons Attribution licence (http://creativecommons.org/licenses/by/4.0/), which permits unrestricted re-use, distribution, and reproduction in any medium, provided the original work is properly cited.

\title{
RADIOCARBON DATES FOR THE LATE PLEISTOCENE AND EARLY HOLOCENE OCCUPATIONS OF COVA ROSA (RIBADESELLA, ASTURIAS, SPAIN)
}

\author{
Esteban Álvarez-Fernández ${ }^{1,2 *}$ (D) Jesús F Jordá Pardo ${ }^{3,2} \cdot$ Pablo Arias $^{4}$ • \\ Julián Bécares $^{1,2} \cdot$ Sergio Martín-Jarque $^{1,2} \cdot$ Rodrigo Portero $^{1,2} \cdot$ Luis Teira $^{4}$ • \\ Katerina Douka ${ }^{5}$ \\ ${ }^{1}$ Dpto. Prehistoria, Historia Antigua y Arqueología, Universidad de Salamanca, Salamanca, Spain \\ ${ }^{2}$ GIR-PREHUSAL, Universidad de Salamanca, Salamanca, Spain \\ ${ }^{3}$ LEP. Dpto. Prehistoria y Arqueología, UNED, Madrid, Spain \\ ${ }^{4}$ Instituto Internacional de Investigaciones Prehistóricas de Cantabria, IIIPC (Gobierno de Cantabria, Universidad de \\ Cantabria y Santander), Spain \\ ${ }^{5}$ Max Planck Institute for the Science of Human History, Department of Archaeology, Jena, Germany
}

\begin{abstract}
Four excavations have been performed at the archaeological site of Cova Rosa (Asturias, Cantabrian Spain): three of them in the second half of last century and the other in this decade. Although little of the archaeological material found in those excavations has been published, here we attempt the stratigraphic correlation of sections revealed by the different excavations and we present 22 new radiocarbon dates for bones and marine shells, built in a Bayesian statistical model. This has enabled the documentation of occupations that mainly took place during the Last Glacial period, in the Solutrean (middle and upper phases) and Magdalenian (archaic, lower, and upper phases), and also in the early Holocene (Mesolithic). These occupations are compared with the record at other sites in Cantabrian Spain in general and in Asturias, in particular.
\end{abstract}

KEYWORDS: ${ }^{14} \mathrm{C}$ chronology, Cantabrian Iberia, Magdalenian, Mesolithic, Solutrean.

\section{INTRODUCTION}

In the last decade, one of the areas in the Iberian Peninsula in which knowledge of prehistoric huntergatherer groups has advanced most is the Sella valley, particularly as regards the transition from the Upper Pleistocene to the early Holocene. This valley, in the east of the Principality of Asturias (northern Spain), is the location of one of the densest concentrations of prehistoric sites in caves and rock-shelters in the whole of the Cantabrian region (e.g., El Cierro Cave, with archaeological levels covering the period from the Mousterian to the Mesolithic, and Tito Bustillo-Dwelling Area, or "Area de Estancia," with intense occupations dated in the Magdalenian), many of which have been made knownin recent publications (see Álvarez-Fernándezand Jordá 2018 for specific bibliography; Figure 1).

Cova Rosa is located in the lower Sella valley. Despite its status as a classic site in Palaeolithic research in northern Spain, owing to the excavations performed by Professor Francisco Jordá Cerdá (FJC) in 1958, the results of later fieldwork at the site (in 1964 and from 1975 to 1979) have remained practically unpublished, even the age of the different levels that were excavated. The remains found during the latter two series of excavations are currently being studied by an interdisciplinary team based at the University of Salamanca. Researchers from the same university have again been excavating and sampling the site since 2017.

The objectives of the present paper are: first, to provide an updated stratigraphic sequence for the Palaeolithic deposit in Cova Rosa, based on a new lithostratigraphic study carried out at the site and its correlation with the stratigraphic sequences presented by past researchers; and second, to present a series of radiocarbon dates that cover all the levels in the sequence and thus place them precisely on the Upper Pleistocene chronoclimate scale.

\footnotetext{
*Corresponding author. Email: epanik@usal.es
} 


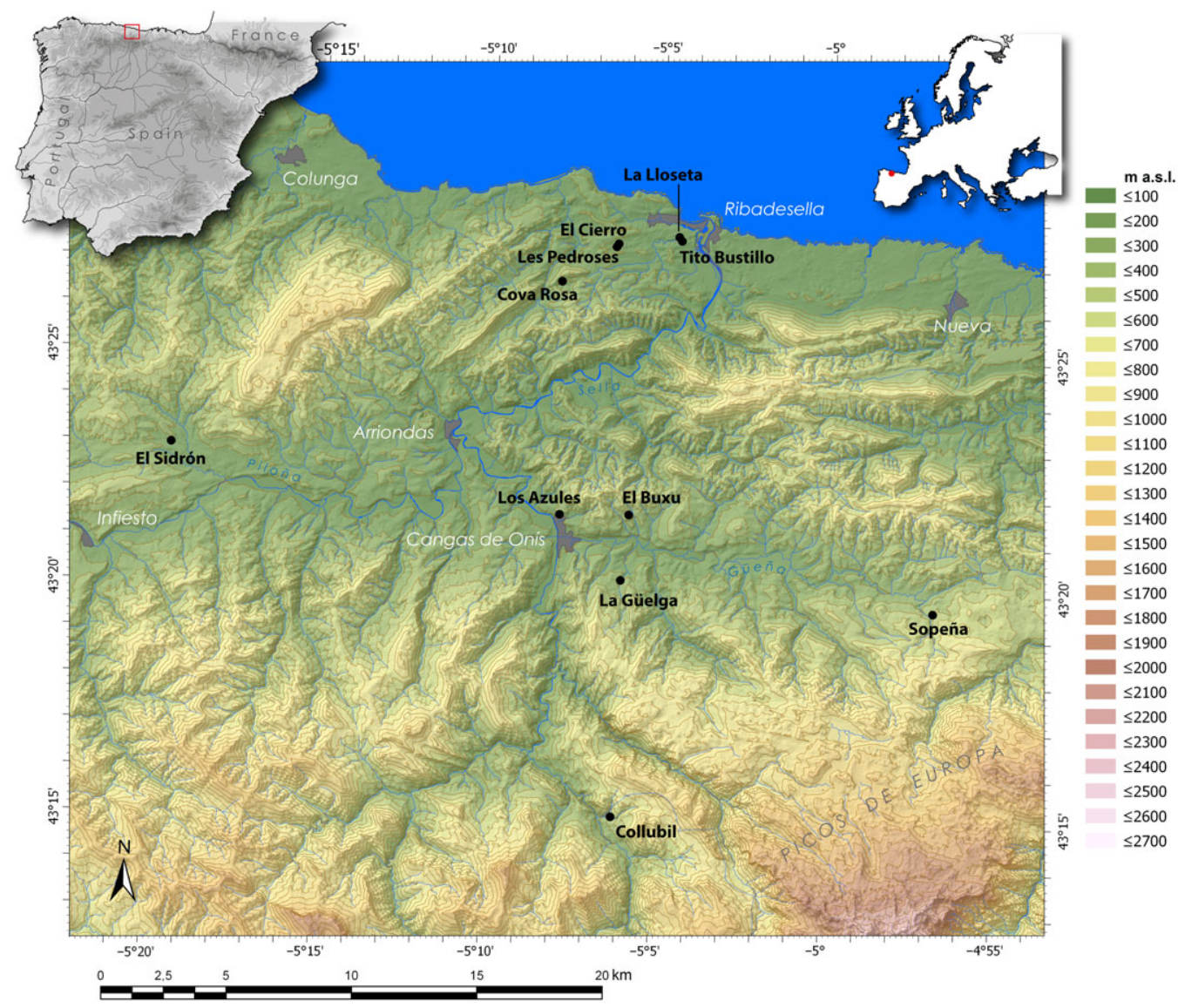

Figure 1 Map of Northern Spain and the Sella River valley in the east of the Principality of Asturias, indicating the most important archaeological sites with occupations during the Late Pleistocene and Early Holocene.

Therefore, a total of 22 radiocarbon dates are presented here, obtained for samples of bones and shells from the archaeological levels documented by the excavations in 1964 and 19751979, and in the recent fieldwork, in 2019. All these samples were analyzed in the Oxford Radiocarbon Accelerator Unit (ORAU) Laboratory at the University of Oxford. These dates provide precise ages for the different occupations in the cave, which have been attributed to the Solutrean, Magdalenian and Mesolithic, based on the archaeological remains found. They also contribute to understand the characteristics of the occupation of the Sella valley in the context of northern Spain, in the late Pleistocene and early Holocene.

\section{COVA ROSA CAVE}

\section{Geographical and Geological Setting}

The archaeological site of Cova Rosa is situated in the small village of Sardéu, Ribadesella Municipality (Asturias, Spain). Its UTM coordinates (ETRS89, Zone 30) are: X=327,289 and $\mathrm{Y}=4,812,217$. It is $4 \mathrm{~km}$ in a straight line from the current coastline, about $3 \mathrm{~km}$ from the neighboring caves with archaeological deposits of Les Pedroses and El Cierro and 5.5 $\mathrm{km}$ from the left bank of the Sella estuary (Figure 1). 
Geologically, Cova Rosa is located at the eastern end of the Asturian Massif in the Cantabrian Range, in a sector with Palaeozoic materials belonging to the Cantabrian Zone of the Iberian Massif. The karstic cave formed in the limestones of the Carboniferous La Escalada Formation (Moscovian) (Navarro et al. 1986). The cave entrance is at $149 \mathrm{~m}$ asl, at the bottom of an endorheic depression, $73 \mathrm{~m}$ deep, in the extreme northwest of a blind valley, at the foot of the limestone ridge called Peña Pagadín (417 m asl) on its southern slope. It is a large rockshelter, $25 \mathrm{~m}$ wide and $15 \mathrm{~m}$ high, which gives access to the cave of the same name, whose entrance is now blocked and can only be accessed with speleological techniques. The small river flowing in the blind valley currently sinks into the karst $23 \mathrm{~m}$ below the rock-shelter, whereas in the Pleistocene the sink was through the rock-shelter. The Cova Rosa karst complex is a long cave system through which the San Miguel River circulates before resurging in the village of Soto. Cova Rosa currently shelters an important bat colony protected under the legal figure of Reserva Natural Parcial de Cova Rosa.

\section{History of Research}

Cova Rosa was discovered in 1957 by FJC. In 1958, after sieving the sediment from the spoil heaps left by unknown people who had dug a large pit, he cleaned a section and excavated a surface area $3 \times 1 \mathrm{~m}$ in size. Based only on the archaeological remains, he distinguished two different periods in the occupation: one dated in the Upper Solutrean and the other in the Lower Magdalenian (Jordá Cerdá 1977). These remains were studied by P. Utrilla (1981) and L. G. Straus (1983), who confirmed FJC's initial attributions (Layers 8-6: Upper Solutrean; Layers 5-2: Lower Magdalenian; and Layer 1: superficial). Additionally, P. Utrilla (1981) and C. González Sainz (1989) noted some artifacts belonging to the Upper Magdalenian, although out of context.

FJC excavated in Cova Rosa again in 1964. A surface area of $3 \times 0.75 \mathrm{~m}$ was studied adjacent to the area excavated in 1958. Recently, based on the excavation logbooks and the study of the archaeological objects found (including the analysis of materials obtained by wet-sieving the sediment samples, which recovered anthracological and above all micro-vertebrate remains), the process of the excavation has been reconstructed and the different levels have been discriminated (Álvarez-Fernández et al. 2018, 2019a). FJC differentiated a disturbed surface level (layer 1) and three geological/archaeological levels which he excavated in 12 layers reaching a depth of approximately 1.40-1.50 m: Level I (layers 2-4) attributed to the Magdalenian; Level II (layers 5-7) with very scarce archaeological material also attributed to the Magdalenian; and Level III (layers 8-12), attributed to the Solutrean. Below layer 12, FJC found "a layer of very compacted calcareous clay," approximately $20-30 \mathrm{~cm}$ thick, without archaeological remains. He did not reach the bedrock of the cave

From 1975 to 1979 FJC and Alejandro Gómez Fuentes (AGF), supported by the geologist Manuel Hoyos Gómez (MHG), carried out an excavation over a surface area covering more than $13 \mathrm{~m}^{2}$ of the rock-shelter (Jordá Cerdá and Gómez 1982) (Figure 2). They documented nine levels, named Cova Rosa A to I. These excavations were carried out following the method of Cartesian coordinates (Laplace 1973) and by subjecting all the extracted sediments to a triple sieve screening. Of the nine levels documented, only Cova Rosa A and Cova Rosa B were dug in the 1970s. Layers A0 and A1 were excavated in Cova Rosa A (10-35 cm thickness). They were provisionally ascribed to the Final Magdalenian-Azilian. Twelve layers were excavated in Cova Rosa B (from the top to the bottom, B1 to B12). Additionally, in order to continue the excavation with more ease, 


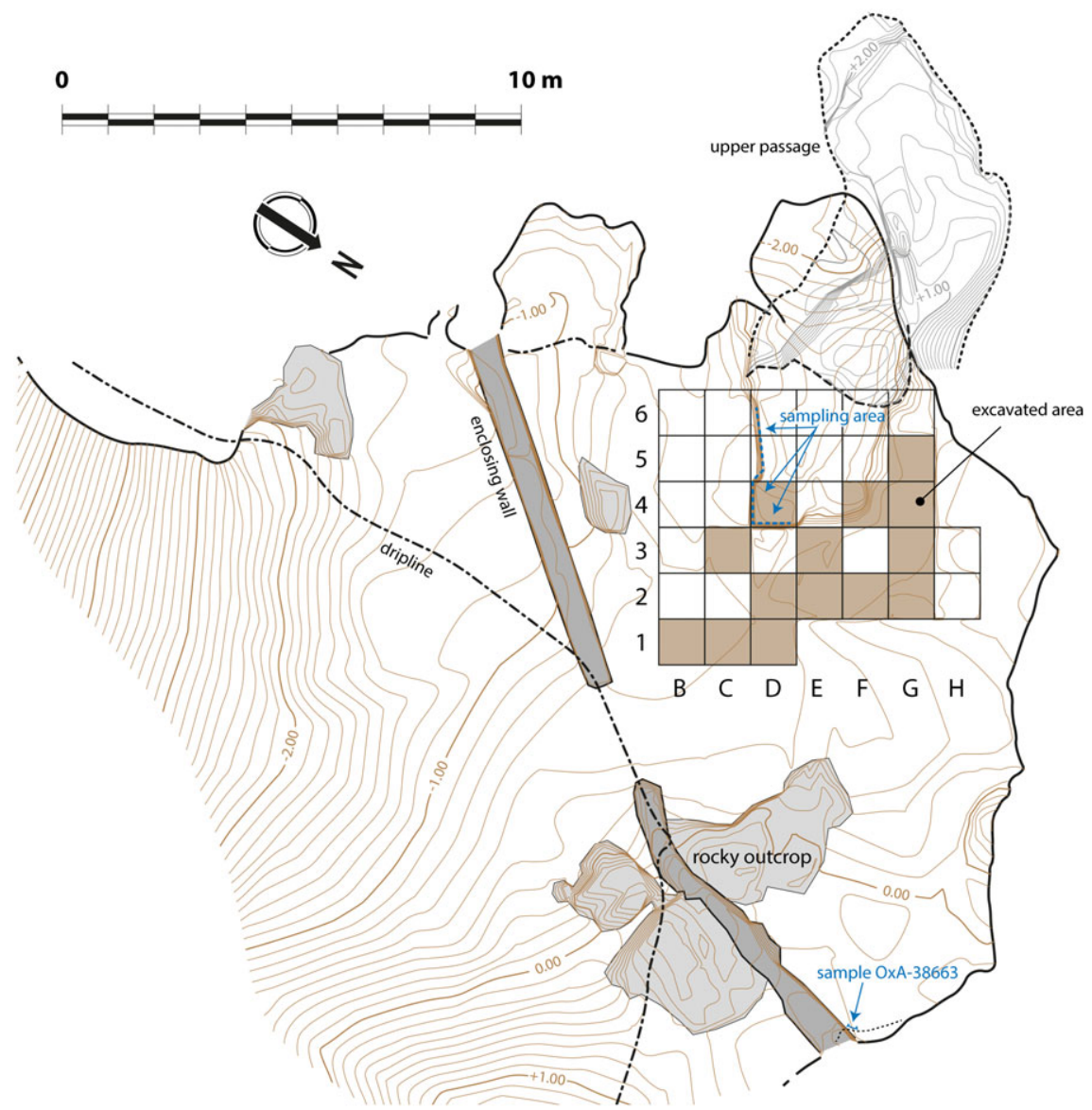

Figure 2 Plan of Cova Rosa, showing the fieldwork area and reproducing the information about the excavations in the 1970s (Jordá Cerdá and Gómez 1982). It shows the approximate place of the excavations carried out by F. Jordá Cerdá in the late 1950s and in 1964.

Square D4 was excavated, and the whole sequence was documented in that area, from the clays at the base to the top. Apart from an interim report on Layer A0 (Jordá Cerdá and Gómez 1982) and a study of the biotic remains in Layer B6, which were assigned to the lower Magdalenian (Álvarez-Fernández et al. 2019b), the work in the 1970s has remained unpublished.

FJC did not date, by radiocarbon or any other method, the archaeological levels that he documented in the different excavations that his team carried out in Cova Rosa during the second half of the last century.

Since 2017 the University of Salamanca has again being carrying out archaeological fieldwork in the cave with the objectives of cleaning up the excavated surfaces and the stratigraphic sections that were still intact, and of collecting different kind of samples (Figure 2). The refreshed sections were those in the outer face (south section) of the 1958 excavation and the south and east sections in Square D4 of the 1975-1979 excavations. In addition, staff from the Archaeozoology Laboratory at the University have collected samples of bones and shells from the 
archaeological levels documented during the last century (in 1964 and in the 1975-1979 excavations) in order to determine the chrono-stratigraphic position of the artifacts found in the past and correlate them with the finds from the new archaeological fieldwork.

\section{Stratigraphy}

After examining the south section of FJC's 1958 excavation and, in more detail, the south section of Square D4, refreshed in 2019, six lithostratigraphic units were identified, which were numbered in increasing order from top to bottom, bearing in mind that further excavations in Square D4 might reveal deeper units. These six units correspond to the six main levels defined by the geologist MHG in his doctoral thesis, which were named with capital letters (from A to F) and which in total reached a maximum thickness of about 1.60 or $2 \mathrm{~m}$. MHG attributed the lower level $(\mathrm{F})$ to the Würm III-IV interglacial, the intermediate levels (E, D, C and B) to the Würm IV and the upper level (A) to the Postglacial period (Hoyos Gómez 1979).

Figure 3 shows the correlation established between the levels described by the researchers who worked in Cova Rosa previously (FJC in 1958 and 1964; FJC, AGF, and MHG from 1975 to 1979) and the units of our own lithostratigraphic sequence obtained in 2019. This has been guided by FJC and AGF's stratigraphic descriptions and MHG's lithostratigraphic sequence. In fact, the correlation shown in Figure 3 was not problematic, thanks to those prior researchers' descriptions, drawings and photographs and the stratigraphic sections currently visible in Cova Rosa. Clear erosive contacts between some of the stratigraphic units, their textural characteristics (clasts and matrix) and their colour facilitated the correlation.

From bottom to top, the lithostratigraphic units observed in the south section in Square D4, where the cave bedrock has not been reached, is as follows (Figure 4):

- CR6. 8-11 cm visible. Very light brown massive silty clay with autochthonous limestone clasts.

- CR5. 20-22 cm. Polyhedral autochthonous limestone pebbles and plaquettes with sharp edges arranged horizontally, in a dark grey-black silty clay matrix.

- CR4. 25-23 cm. Polyhedral autochthonous limestone pebbles with sharp edges, in an abundant brown silty clay matrix.

- CR3. 34-22 cm. Polyhedral autochthonous limestone boulders and pebbles with sharp edges, and some plaquettes. Abundant grey-black silty clay matrix.

- CR2. 25-42 cm. Polyhedral autochthonous limestone pebbles with sharp edges, in a grey silty clay matrix. The contact with the underlying layer is clearly erosive.

- CR1. 24-20 cm. Light beige silts and clays with a massive appearance and very compact. Some polyhedral autochthonous limestone pebbles with sharp edges and some very rounded ones. Limestone plaquettes also appear. The surface of the contact with the underlying layer is erosional.

- CR1sup. 0-50 cm. Angular autochthonous limestone boulders and rocks, with plaques and clasts that have fragmented after their sedimentation. The matrix is formed by very compact light beige silt and clay with a massive appearance. This layer only appears in the western part of the south section, towards the interior of the cave and outside Square D4. 


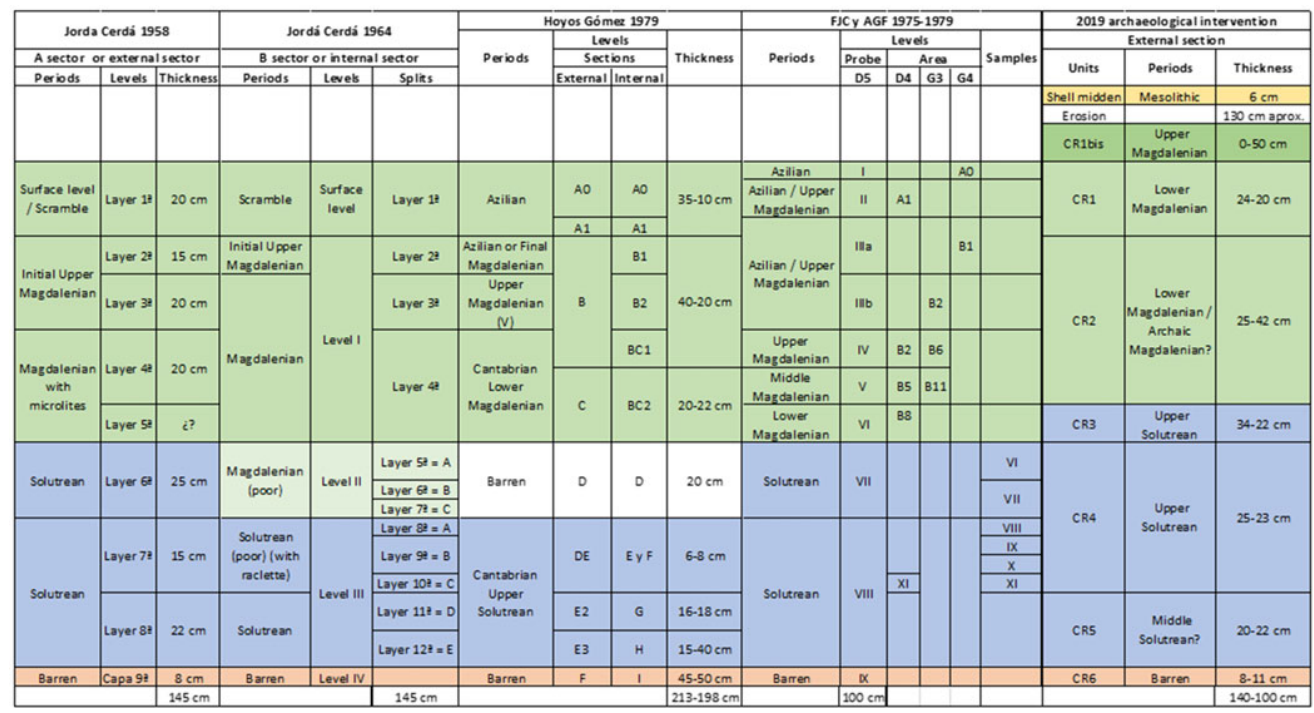

Figure 3 Stratigraphic correlations across the three excavations at Cova Rosa.
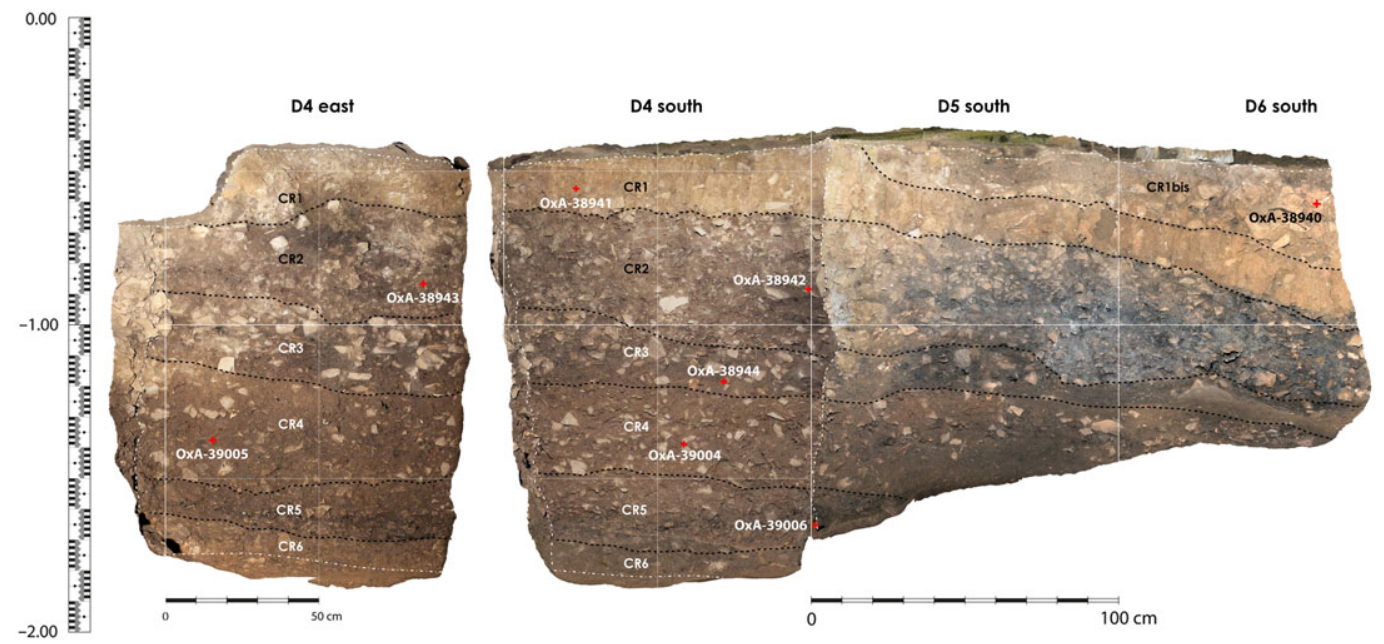

Figure 4 Stratigraphic section of the excavation at Cova Rosa.

A few remains of a strongly cemented shell-midden (CR-conch.) are adhered to the rock-shelter wall, $1.5 \mathrm{~m}$ above the current floor (top of CR 1 and CR 1 sup.). Therefore, a large stratigraphic gap exists between the deposit that forms the fill in the rock-shelter and the organogenic deposit of this shell-midden; this would be the consequence of erosion after their sedimentation.

Based on its sedimentological characteristics, the lowest unit in the sequence (CR6) might correspond to the late OIS 3, which was very cold, coinciding with Heinrich Event 2, while 
the detritic sequence, from CR5 to CR1sup would correspond to the coldest phases of OIS 3 (Last Glacial Maximum): the stadials GS2c, GS2b, and GS2a. In turn, the shell-midden (CRconch.) would belong to the first millennia of the Holocene, in the warmer and wetter conditions of the Greenlandian.

\section{RADIOCARBON DATES AT COVA ROSA}

\section{Method}

Of the 22 samples that have been dated, three correspond to bones from FJC's 1964 excavation, ten from FJC and AGF's 1975-1979 excavations (two shells and eight bones), and nine were collected during the 2019 fieldwork (one shell and eight bones).

Shell and bone samples were chosen for radiocarbon dating as those remains have been found in abundance in the different excavations carried out in Cova Rosa. The preferred dating material was bone and, wherever possible, we selected bones for which the taxon and anatomical element could be identified and which displayed cutmarks as evidence of anthropic activity. However, in the uppermost layers excavated in 1975-1979 (A0, B1 and B6) marine mollusk shells were selected instead, either the periwinkle Littorina littorea, or the common limpet, Patella vulgata. This was because osseous remains in those layers were fragmented and altered by natural agents and post-depositional processes (the cave was used as an animal pen until quite recently). Moreover, those two gastropod species were the ones most widely consumed as food in the late glacial period in northern Spain, where they are abundant at archaeological sites located near the coast (Álvarez-Fernández et al. 2019a). In the case of the 2019 fieldwork, the only shell sample (Phorcus lineatus) came from the small remnants of a shell-midden adhered to the rock-shelter wall of the cave, where only mollusk shells have been documented. Charcoal fragments that could potentially be dated were also recovered in the 1964 and 1975-1979 excavations. Their presence was recorded in the excavation logbooks and has been confirmed in the sediment floating and screening process. They are currently being studied.

Routine radiocarbon protocols as applied at the Oxford Accelerator Unit (ORAU, Oxford, UK) were used for the dating of the samples (Brock et al. 2010). The shells (OxA-38,663, $31,706,31,707,31,708$ ) underwent the pretreatment for biogenic carbonates as this is applied at the ORAU (phosphoric acid dissolution). In the case of bone samples, some were dated using ultrafiltration (OxA-38,940, 38,941, 38,942, 38,943, 38,944, 39,004, $39,005,39,006$ ) and the rest using the simpler ABA method (ABA: OxA-38,268, 38,269, $38,270,38,271,38,272,38,273,38,274)$. The selection of the ABA method over ultrafiltration was based on the physical inspection of each sample and the assumption that some bones may not preserve sufficient collagen. This turned out not to be true as collagen yields ranged between $1.2-9.5 \%$ and no bone sample failed to yield collagen.

In addition, in order to place the human occupations at Cova Rosa on the chrono-stratigraphic scale for the late Upper Pleistocene currently in use, based on the Greenland Events (Björck et al. 1998), we have compared the radiocarbon dates from Cova Rosa with the NGRIP oxygen isotopic data used here as palaeoclimate proxy (Svensson et al. 2008). 


\section{Validity Analysis}

The radiocarbon results have been subjected to a validity test (Mestres 1995, 2000, 2003, 2008) to determine that they meet the basic requirements for such dates. These requirements are of chemico-physical, analytical and archaeological types.

The chemico-physical requirements refer to the capacity of the material to provide a valid radiocarbon date. The 22 samples from Cova Rosa are all organic materials (18 bone fragments and 4 mollusk shells) and therefore satisfy those conditions perfectly.

The analytical requirements that radiocarbon dates should meet refer to their accuracy (elimination of contamination, chemical treatment and measurement of the ${ }^{14} \mathrm{C}$ content) and precision (standard deviation) and are related to laboratory quality control. The values related to the accuracy of the results include $\%$ collagen or yield, $\% \mathrm{C}$ and $\mathrm{C} / \mathrm{N}$ ratio for bone samples; the latter is often regarded an indicator than no exogenous $\mathrm{C}$ was present in the dated sample. In the case of the Cova Rosa bones, the $\mathrm{C} / \mathrm{N}$ ratio ranged between 3.13.3 , the collagen yield ranged between $1.2-9.5 \%$ and the $\% \mathrm{C}$ in the combusted gelatine was between 40.2-44.5; all values fall well within expected ranges.

The requirement of precision specifies that the standard deviation of the radiocarbon results should be as small as possible. This is met by the results provided by the ORAU, as the deviations are smaller than or equal to 110 years, which is considered reasonable for this time in the Pleistocene. Two are smaller than 50 years, seven are between 50 and 65, eight between 80 and 90 , and five are larger than 90 radiocarbon years.

Finally, in archaeological terms, a radiocarbon date should be representative of the event that it is attempting to determine chronologically. That is to say, a close correspondence should exist between the physical age of the dated sample and the archaeological age of the context or event being dated. It should therefore fulfill two essential conditions: first, the material itself or its presence in the archaeological deposit should be a product of the biological or technical activity of the human group that created the deposit (association), and second its formation should be contemporaneous with the human group that created the archaeological deposit (synchronicity). As regards their association, we can be reasonably certain that the dated samples (bones and shells) are loosely linked to the anthropic activity that created the different levels in the deposit. Similarly, all the samples correspond to organisms with a short life (red deer and marine gastropods), except for two bone samples from an unknown species, and therefore they can be considered synchronic with the anthropic activity that deposited them at the site. However, two of the results does not appear to represent a time that agrees with the age of its stratigraphic position, and these anomalies will be discussed below.

All the calibrated dates that appear in the text are given with confidence intervals of $68 \%$ or $95 \%$. The comparisons with dates from other sites are made after recalibrating them with the same calibration curve as used in the present study.

\section{Results and Critical Assessment}

Table 1 presents the dates obtained in the different archaeological fieldwork seasons (1964, 19751979, and 2019) and Table 2 and Figure 5 the calibration of these dates, in reverse stratigraphic order. Calibration was performed using IntCal20 and Marine20, and for the shell samples we used also a regional marine radiocarbon reservoir correction of $-117 \pm 70$ for the late Pleistocene samples and $-105 \pm 21$ for the Early Holocene ones as established by Soares 
Table 1 Raw radiocarbon determinations from Cova Rosa and their isotopic values.

\begin{tabular}{|c|c|c|c|c|c|c|c|c|c|c|c|c|c|}
\hline \multicolumn{14}{|c|}{ Excavations 1964} \\
\hline Square & Level & Split & Period $^{\mathrm{a}}$ & $\begin{array}{l}\text { Date } \\
\text { BP }\end{array}$ & $\begin{array}{c}1 \\
\text { sigma }\end{array}$ & Material $^{\mathrm{b}}$ & Lab nr & $\begin{array}{l}\text { Used } \\
(\mathrm{mg})\end{array}$ & $\begin{array}{l}\text { Yield } \\
(\%)\end{array}$ & $\% \mathrm{C}$ & $\delta^{13} \mathrm{C}$ & $\delta^{15} \mathrm{~N}$ & $\mathrm{C} / \mathrm{N}$ \\
\hline$\overline{\mathrm{E} / \mathrm{F} 4-6}$ & $\mathrm{I}$ & 4 & $\begin{array}{l}\text { A./L. } \\
\text { Mag. }\end{array}$ & 16800 & 80 & B-Phalanx (C.e.) & OxA-31799 & 600 & 2.8 & 43 & -20.4 & 6.7 & 3.2 \\
\hline $\mathrm{E} / \mathrm{F}$ 4-6 & I & 4 & $\begin{array}{c}\text { A./L. } \\
\text { Mag. }\end{array}$ & 16820 & 90 & B-Phalanx (C.e.) & OxA-31800 & 620 & 3.4 & 43.8 & -20.3 & 6.1 & 3.2 \\
\hline $\mathrm{E} / \mathrm{F} 4-6$ & II & 7 & $\begin{array}{c}\text { M./U. } \\
\text { Sol. }\end{array}$ & 18550 & 100 & $\begin{array}{l}\text { B-Metacarpal V } \\
\quad \text { (C.e.) }\end{array}$ & OxA-31801 & 610 & 5.1 & 42.6 & -20.6 & 5.6 & 3.1 \\
\hline \multicolumn{14}{|c|}{ Excavations 1975-1979 } \\
\hline Square & Level & Split & Period & $\begin{array}{l}\text { Date } \\
\text { BP }\end{array}$ & $\begin{array}{c}1 \\
\text { sigma }\end{array}$ & Material & Lab nr & $\begin{array}{l}\text { Used } \\
(\mathrm{mg})\end{array}$ & $\begin{array}{l}\text { Yield } \\
(\%)\end{array}$ & $\% \mathrm{C}$ & $\delta^{13} \mathrm{C}$ & $\delta^{15} \mathrm{~N}$ & $\mathrm{C} / \mathrm{N}$ \\
\hline$\overline{\mathrm{G} 4}$ & $\mathrm{~A}$ & 0 & L. Mag. & 15860 & 65 & $\mathrm{~S}(P . v)$. & OxA-31706 & 37.8 & 10.3 & 101.1 & -0.25 & - & \\
\hline G4 & B & 1 & U. Mag.? & 13970 & 55 & $\mathrm{~S}(P . v)$ & OxA-31707 & 43.9 & 10.5 & 98.6 & 0.44 & - & \\
\hline G3 & B & 6 & L. Mag. & 15385 & 80 & $\begin{array}{l}\text { B-Phalanx } 2 \\
\text { (C.e.) }\end{array}$ & OxA-38273 & 548 & 5.6 & 43 & -20.5 & 4.4 & 3.2 \\
\hline G3 & B & 6 & L. Mag. & 15810 & 60 & $\mathrm{~S}(L . l)$. & OxA-31708 & 44.7 & 10.5 & 111.3 & -0.16 & - & \\
\hline G3 & B & 11 & $\begin{array}{l}\text { A./L. } \\
\text { Mag. }\end{array}$ & 16640 & 90 & $\begin{array}{l}\text { B-Metatarsal } \\
\text { WCM (C.e.) }\end{array}$ & OxA-38274 & 498 & 3.9 & 41.7 & -21.3 & 5.3 & 3.2 \\
\hline D4 & B & 2 & L. Mag. & 15715 & 80 & $\begin{array}{l}\text { B-Mandible } \\
\text { WCM (C.e.) }\end{array}$ & OxA-38268 & 556 & 4.3 & 43.9 & -20.3 & 4.2 & 3.2 \\
\hline D4 & B & 5 & $\begin{array}{l}\text { A./L. } \\
\text { Mag. }\end{array}$ & 16400 & 90 & $\begin{array}{l}\text { B-Metatarsal } \\
\text { WCM (C.e.) }\end{array}$ & OxA-38269 & 628 & 3.6 & 40.2 & -20.7 & 4.2 & 3.1 \\
\hline D4 & B & 8 & U. Sol. & 17600 & 100 & $\begin{array}{l}\text { B-Metatarsal } \\
\quad(\text { C.e. })\end{array}$ & OxA-38270 & 582 & 1.4 & 41.2 & -21 & 4.4 & 3.2 \\
\hline D4 & 1st Sol. & - & $\begin{array}{l}\text { M./U. } \\
\text { Sol. }\end{array}$ & 17800 & 100 & $\begin{array}{l}\text { B-Metapod } \\
\text { DEP (C.e.) }\end{array}$ & OxA-38271 & 550 & 5.8 & 41.9 & -21 & 4 & 3.2 \\
\hline D4 & $\mathrm{XI}$ & - & $\begin{array}{l}\text { M./U. } \\
\text { Sol. }\end{array}$ & 18330 & 110 & $\begin{array}{l}\text { B-Phalanx } 2 \\
\text { (C.e.) }\end{array}$ & OxA-38272 & 599 & 9.5 & 43.1 & -21.3 & 3.8 & 3.2 \\
\hline \multicolumn{14}{|c|}{ Excavations 2019} \\
\hline Square & Level & Split & Period & $\begin{array}{l}\text { Date } \\
\text { BP }\end{array}$ & $\begin{array}{c}1 \\
\text { sigma }\end{array}$ & Material & Lab nr & $\begin{array}{l}\text { Used } \\
(\mathrm{mg})\end{array}$ & $\begin{array}{l}\text { Yield } \\
(\%)\end{array}$ & $\% \mathrm{C}$ & $\delta^{13} \mathrm{C}$ & $\delta^{15} \mathrm{~N}$ & $\mathrm{C} / \mathrm{N}$ \\
\hline & SM N & - & Mesol. & 7164 & 23 & $\mathrm{~S}(P . l)$. & OxA-38663 & 100 & 6.9 & 98.7 & -1.4 & & \\
\hline D6 (S) & $\begin{array}{l}\text { CR1 } \\
\text { BIS }\end{array}$ & - & U. Mag. & 12949 & 45 & B-Radius indet. & OxA-38940 & 591 & 1.2 & 44.6 & -21 & 3.5 & 3.3 \\
\hline D4 (S) & CR1 & - & L. Mag. & 14867 & 54 & B-indet. & OxA-38941 & 648 & 6.9 & 44.5 & -20.3 & 4.6 & 3.3 \\
\hline D4 (E) & $\mathrm{CR} 2$ & - & $\begin{array}{l}\text { A./L. } \\
\text { Mag. }\end{array}$ & 16360 & 64 & $\begin{array}{l}\text { B-Metacarpal } \\
\text { (C.e.) }\end{array}$ & OxA-38943 & 682 & 3.2 & 43.9 & -21 & 4.5 & 3.3 \\
\hline D4 (S) & $\mathrm{CR} 2$ & - & $\begin{array}{l}\text { A./L. } \\
\text { Mag. }\end{array}$ & 16408 & 65 & $\begin{array}{l}\text { B-Metacarpal } \\
\text { (C.e.) }\end{array}$ & OxA-38942 & 665 & 3.4 & 43.3 & -21.9 & 4.5 & 3.3 \\
\hline D4 (S) & CR3 & - & U. Sol. & 17609 & 54 & $\begin{array}{l}\text { B-Metapod } \\
\text { (C.e.) }\end{array}$ & OxA-38944 & 577 & 2.6 & 44.3 & -21.1 & 4.3 & 3.3 \\
\hline D4 (S) & CR4 & - & $\begin{array}{l}\text { M./U. } \\
\text { Sol. }\end{array}$ & 18367 & 83 & $\begin{array}{l}\text { B-Metapod } \\
\quad(\text { C.e. })\end{array}$ & OxA-39004 & 561 & 3.8 & 43.5 & -21.4 & 3.9 & 3.2 \\
\hline D4 (E) & CR4 & - & $\begin{array}{l}\text { M./U. } \\
\text { Sol. }\end{array}$ & 18410 & 82 & $\begin{array}{l}\text { B-Metapod } \\
\quad(\text { C. e. })\end{array}$ & OxA-39005 & 619 & 3.8 & 43.9 & -20.5 & 3.9 & 3.2 \\
\hline D4 (E) & CR5 & - & M. Sol.? & 19714 & 97 & $\begin{array}{l}\text { B-Metapod } \\
\quad \text { (C.e.) }\end{array}$ & OxA-39006 & 616 & 3.2 & 44.3 & -21.1 & 2.8 & 3.2 \\
\hline
\end{tabular}

aPeriods: M. Sol., Middle Solutrean; U. Sol., Upper Solutrean; A. Mag., Archaic Magdalenian; L. Mag., Lower Magdalenian; U. Mag., Upper Magdalenian; Mes., Mesolithic; SM, Shell midden.

${ }^{b}$ Materials: B-, Bone (C. e., Cervus elaphus); S-, Marine shell (P. v., Patella vulgata; L. 1., Littorina littorea; P. 1., Phorcus lineatus); WCM, with cut marks.

et al. (2016). Further to this, to verify the validity of this local offset we dated a marine shell and a bone sample from the same Lower Magdalenian context (B6). We obtained two dates, OxA38273: $15385 \pm 80$ (bone) and OxA-31708: $15810 \pm 60$ (shell) which after calibration and correction for the global and local reservoirs agree well with the aforementioned value. 
Table 2 Calibrated dates from Cova Rosa, with ranges at $68.2 \%$ and $95.4 \%$ probability. The raw radiocarbon determinations have been calibrated with OxCal 4.3 software (Bronk Ramsey 2001, 2009a, 2009b) against the IntCal20 calibration curve (Reimer et al. 2020) for terrestrial samples and the Marine20 curve for marine ones, with a $\Delta \mathrm{R}=-117 \pm 70$ established for the late Pleistocene and $\Delta \mathrm{R}=-105 \pm 21$ for the Early Holocene in the region (Soares et al. 2016).

\begin{tabular}{lcccc}
\hline & \multicolumn{3}{c}{ Calibrated dates (BP) } \\
\cline { 2 - 3 } & \multicolumn{2}{c}{$68.24 \%$} & & $95.46 \%$ \\
\cline { 2 - 3 } & From & To & From & To \\
\hline Excavations 1964 & & & & \\
OxA-31799 & 20440 & 20220 & 20510 & 20090 \\
OxA-31800 & 20460 & 20230 & 20540 & 20080 \\
OxA-31801 & 22550 & 22340 & 22840 & 22270 \\
Excavations 1975-1979 & & & & \\
OxA-31706 & 18610 & 18300 & 18730 & 18180 \\
OxA-31707 & 16350 & 16030 & 16520 & 15870 \\
OxA-38273 & 18810 & 18650 & 18860 & 18320 \\
OxA-31708 & 18570 & 18270 & 18690 & 18150 \\
OxA-38274 & 20240 & 19970 & 20380 & 19870 \\
OxA-38268 & 19060 & 18880 & 19150 & 18830 \\
OxA-38269 & 19890 & 19610 & 20050 & 19550 \\
OxA-38270 & 21410 & 21060 & 21720 & 20930 \\
OxA-38271 & 21800 & 21430 & 22000 & 21290 \\
OxA-38272 & 22380 & 22170 & 22460 & 22050 \\
Excavations 2019 & & & & \\
OxA-38663 & 7620 & 7480 & 7680 & 7420 \\
OxA-38940 & 15590 & 15380 & 15650 & 15290 \\
OxA-38941 & 18250 & 18160 & 18280 & 18040 \\
OxA-38943 & 19840 & 19620 & 19910 & 19550 \\
OxA-38942 & 19890 & 19620 & 19990 & 19570 \\
OxA-38944 & 21400 & 21150 & 21450 & 21010 \\
OxA-39004 & 22400 & 22230 & 22460 & 22130 \\
OxA-39005 & 22420 & 22270 & 22490 & 22170 \\
OxA-39006 & 23850 & 23430 & 23930 & 23360 \\
\hline & & & &
\end{tabular}

The results are discussed below, within the periods they belong to, in decreasing chronological order.

In an attempt to assess the coherence of the chrono-stratigraphic sequence in a probabilistic way, we incorporate the new results from Cova Rosa into a Bayesian statistical framework. We used the OxCal 4.4 platform (Bronk Ramsey et al. 2009a) to combine the radiocarbon likelihoods with the relative stratigraphic information available from the site. We use a sequence in which nested are four sequences/phases representing the distinct archaeological periods (Solutrean, Lower Magdalenian, Upper Magdalenian, Mesolithic).

We used an outlier detection analysis (Bronk Ramsey 2009b) that measures probabilistically the degree to which determinations agree within the overall model structure and its components. We used a t-type outlier model, and assigned 5\% chances for each 


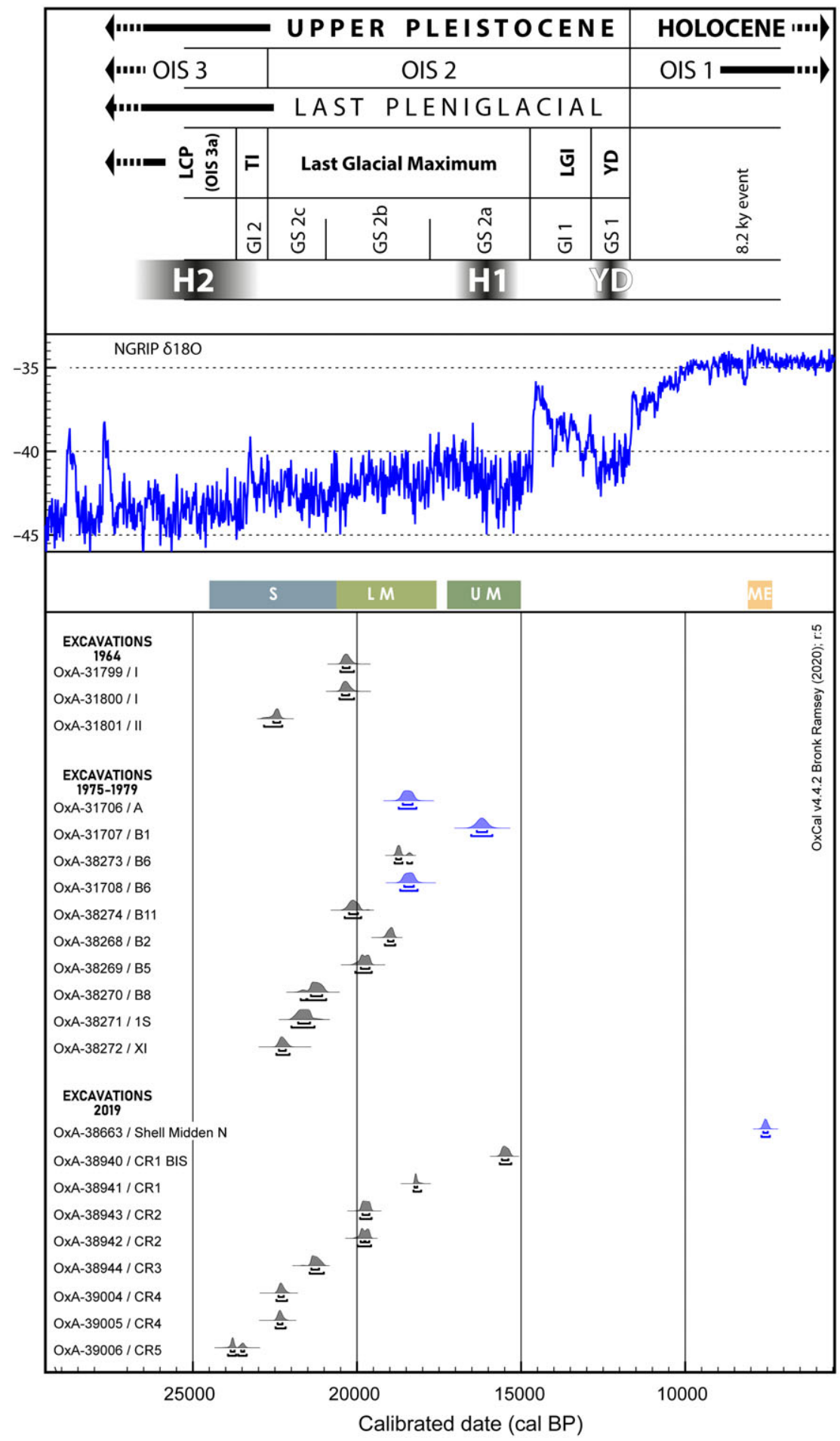

Figure 5 Calibration of the dates obtained at Cova Rosa with the IntCa120 and Marine20 curves (Heaton et al. 2020; Reimer et al. 2020). In black the terrestrial samples, in blue the marine ones. The NGRIP oxygen isotope record, showing palaeoclimatic variations (Svensson et al. 2008), is reproduced at the top of the graph. The provenance of each of the radiocarbon dates is indicated next to their OxA code. 
determination to be an outlier. Each phase in the model is separated by two boundaries, to better account for the time required for observed time lag between archaeological phases.

The Bayesian results are shown in Figure 6 and Table 3. No outlier was identified in the dataset, and with the exception of OxA-31801 which showed a slightly elevated chance of being an outlier $(23 \%)$ all other dates agreed well with the model $(>95 \%)$.

\section{Solutrean}

Eight dates were obtained for the Solutrean units.

In Unit CR5 (Square D4 south), the only date (OxA-39006, 23,930-23,360 cal BP, Sample 3151) places the unit in the late GS 3, which was the coldest phase of OIS 3a, at the end of the Heinrich Event (HE) 2. This is in fact the coldest period in the whole sequence at Cova Rosa. Archaeologically, it may be attributed to the middle Solutrean.

Two dates correspond to Unit CR4 (Square D4 south): (OxA-39005, sample 3159 and OxA39004 , sample 3152) which situate the level in the interval ca. 22,500-22,200 cal BP. These two dates are statistically identical. This time corresponds to a short cold phase that followed a temperate period at the beginning of Stadial GS2c. These two dates correlate perfectly with results for samples obtained in earlier fieldwork, both OxA-31801, for Level II Spit 7 in 1964, in which upper Solutrean industry was documented (Álvarez-Fernández et al. 2018), and OxA-38272, from Level XI (Square D4) in the 1979 fieldwork.

OxA-38271, from a sample deriving the so-called " $1{ }^{\text {st }}$ Solutrean" Square D4) in the 1979 excavation, dated to 22,000-21,290 cal BP, which would have been at the top of Unit CR4. It may be associated with the steep fall in temperature in Stadial GS2c. CR4 is assignable to the middle or upper Solutrean.

One date was obtained from Unit CR3 (Square D4 south). OxA-38944 (Sample 3153), from the base of the unit, dates to 21,450-21,010 cal BP. This result can be correlated with OxA-38270, for a sample from Level B Spit 8 (Square D4) in the 1978 fieldwork. They correspond to the coldest moment in Stadial GS2c. Archaeologically, Unit CR3 can probably be attributed to the upper Solutrean.

The results obtained for Units CR5, CR4 and CR3 are coherent with the archaeological remains attributed to the Solutrean documented in the excavations in 1958 (Jordá Cerdá 1977; Straus 1983) and 1964 (Álvarez-Fernández et al. 2018) in Cova Rosa. A large number of objects with flat-covering retouch characteristic of the Solutrean were found in those levels. Of differing typology (shouldered, concave-based, and laurel-leaf points), they are made in quartzite and different types of flint. In 2019, a further 20 pieces with this characteristic type of retouch were collected out of context when removing sediment fallen from the sections and before taking samples.

In the Bayesian model we placed the dates of the Solutrean units in a sequence to accommodate for the prior stratigraphic knowledge we have for them. The start of the Solutrean is modeled between $24,130-23,430$ or $24,860-22,410$ cal BP (at $68.2 \%$ or $95.4 \%$ respectively), and the end of the Solutrean at the site about 3 millennia later at 21,000 cal BP, or between 21,230-20,810/ 21,340-20,520 cal BP (at 68.2\%/95.4\% respectively; Table 3, Figure 6). 


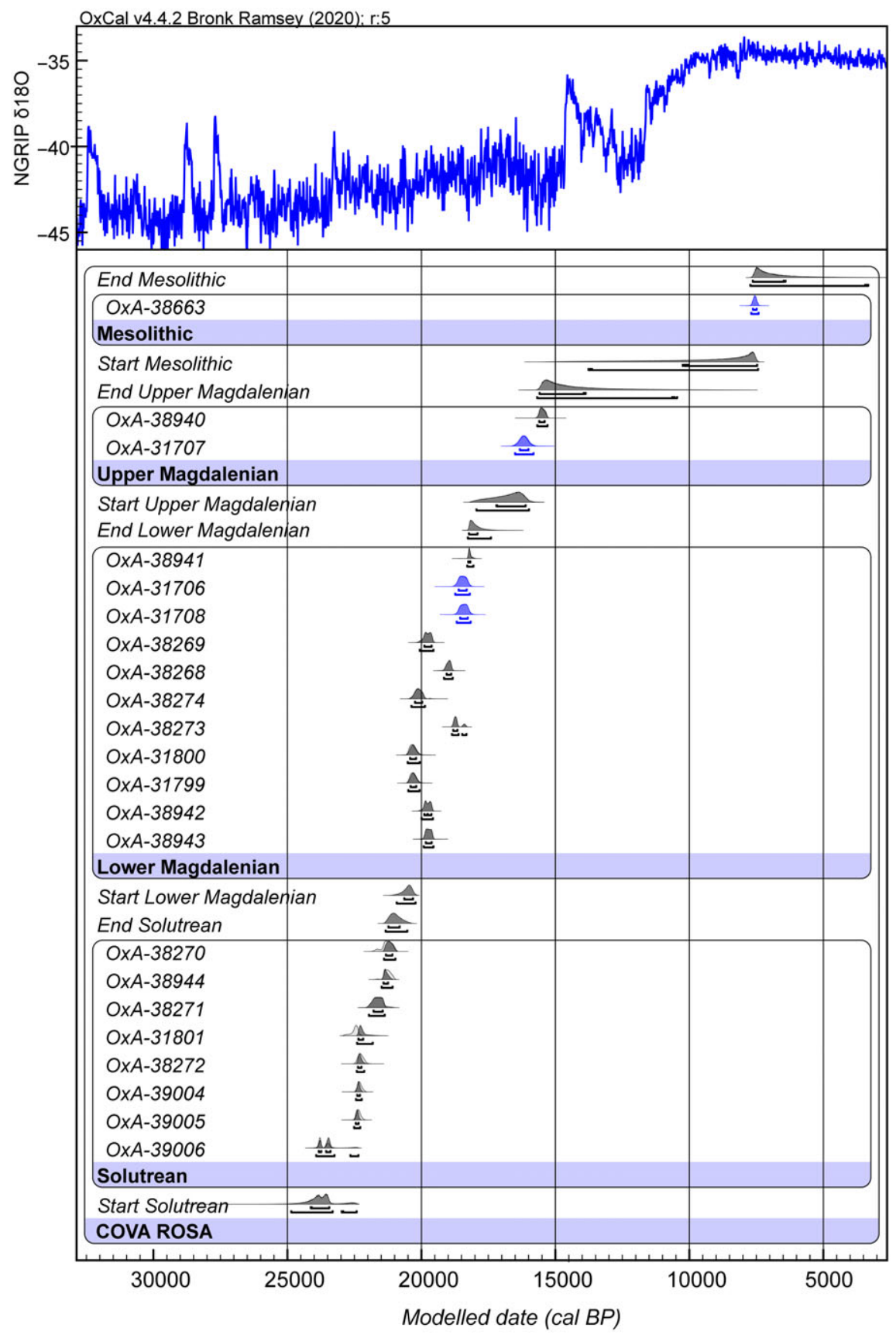

Figure 6 Bayesian model (cal BP) of the radiocarbon dates at Cova Rosa.

\section{Magdalenian}

Thirteen dates have been obtained for the Magdalenian levels.

Two samples were taken in 2019 for Unit CR2 (Square D4): OxA-38943, in the middle part of the east section and OxA-38942, in the middle part of the south section. Both results fall in the 
Table 3 Bayesian modeled dates (cal BP) at Cova Rosa using OxCal software.

\begin{tabular}{|c|c|c|c|c|}
\hline & \multicolumn{4}{|c|}{ Bayesian modeled dates (cal BP) } \\
\hline & \multicolumn{2}{|c|}{$68.26 \%$} & \multicolumn{2}{|c|}{$95.44 \%$} \\
\hline & From & To & From & To \\
\hline \multicolumn{5}{|l|}{ Mesolithic } \\
\hline OxA-38663 & 7630 & 7480 & 7690 & 7410 \\
\hline \multicolumn{5}{|l|}{ Upper Magdalenian } \\
\hline OxA-38940 & 15610 & 15390 & 15680 & 15290 \\
\hline OxA-31707 & 16330 & 16000 & 16510 & 15810 \\
\hline \multicolumn{5}{|l|}{ Archaic/Lower Magdalenian } \\
\hline OxA-38941 & 18250 & 18170 & 18290 & 18050 \\
\hline OxA-31706 & 18610 & 18310 & 18740 & 18190 \\
\hline OxA-31708 & 18560 & 18260 & 18680 & 18160 \\
\hline OxA-38269 & 19890 & 19610 & 20070 & 19540 \\
\hline OxA-38268 & 19060 & 18880 & 19160 & 18830 \\
\hline OxA-38274 & 20240 & 19970 & 20380 & 19860 \\
\hline OxA-38273 & 18820 & 18650 & 18860 & 18310 \\
\hline OxA-31800 & 20430 & 20200 & 20510 & 20060 \\
\hline OxA-31799 & 20410 & 20190 & 20490 & 20060 \\
\hline OxA-38942 & 19890 & 19620 & 20000 & 19560 \\
\hline OxA-38943 & 19840 & 19610 & 19920 & 19540 \\
\hline \multicolumn{5}{|l|}{ Solutrean } \\
\hline OxA-38270 & 21330 & 21080 & 21400 & 20970 \\
\hline OxA-38944 & 21420 & 21240 & 21490 & 21070 \\
\hline OxA-38271 & 21790 & 21440 & 21960 & 21360 \\
\hline OxA-31801 & 22350 & 22170 & 22400 & 21810 \\
\hline OxA-38272 & 22370 & 22230 & 22410 & 22130 \\
\hline OxA-39004 & 22400 & 22290 & 22450 & 22220 \\
\hline OxA-39005 & 22450 & 22340 & 22510 & 22280 \\
\hline OxA-39006 & 23830 & 23390 & 23930 & 22350 \\
\hline \multicolumn{5}{|l|}{ Boundaries } \\
\hline Start Solutrean & 24130 & 23430 & 24860 & 22410 \\
\hline End Solutrean & 21230 & 20810 & 21340 & 20520 \\
\hline Start Lower Magdalenian & 20640 & 20310 & 20930 & 20210 \\
\hline End Lower Magdalenian & 18230 & 17900 & 18270 & 17400 \\
\hline Start Upper Magdalenian & 17200 & 16110 & 17950 & 15980 \\
\hline End Upper Magdalenian & 15590 & 13870 & 15680 & 10450 \\
\hline Start Mesolithic & 10250 & 7460 & 13770 & 7430 \\
\hline End Mesolithic & 7640 & 6410 & 7730 & 3320 \\
\hline
\end{tabular}

ca. 20,000-19,500 cal BP interval, a slightly more temperate time of amelioration in Stadial GS2b followed by a later fall in temperature. These two dates correlated with the samples obtained in 1964 in Level I, Spit 4 (Square E/F 4-6); both OxA-31800 and OxA-31799. They are associated with characteristic artifacts like bladelet cores/nucleiform endscrapers. In this level, while the most abundant raw materials are local (quartzite and local flint types), others are from more distant sources in northern Spain (Flysch-type flint) and Aquitaine ("grain de mil" type) (Álvarez-Fernández et al. 2020b). The radiocarbon results 
correspond archaeologically to a period called archaic Magdalenian in the regional classification.

These dates for CR2 are also correlated with two others for Level B in the 1975-1979 excavations: OxA-38274, from Square G3, Spit 11; and OxA-38269, from Square D4, Spit 5. These results can also be linked to OxA-31706 from Square G4 in Level A0, which however appears to represent secondary contamination from Level B that could not be identified during the excavation of Level A0.

The other three samples, OxA-31708, OxA-38273 and OxA-38268, also correspond to Unit CR2. They come from Level B in the 1975-1979 excavations but are about a millennium younger than the previous dates (ca. 19,200-18,500 cal BP). They come from the top of the level. The first two samples were taken in Square G3, both of them in Spit 6 (one was a shell of L. littorea and the other a Cervus elaphus bone). Detailed information about the use of biotic resources is available for this level, in which hunting specialised in red deer, and shellfishing and fishing were practiced. The palaeoenvironmental data from the anthracological study indicates open vegetation with a predominance of shrub taxa whereas the small mammal assemblage suggests a cold humid climate (Álvarez-Fernández et al. 2019a).

The third of these dates (OxA-38268) was obtained from a sample from Square D4, Spit 2. Information about the lithic assemblage comes from a preliminary study of this square. It is characterised by an abundance of geometric microliths, backed bladelets and, above all, triangles shorter than $1 \mathrm{~cm}$ in length. The calibrated interval of this date would correspond to the warmest time in the middle of GS2b and the slight cooling immediately afterwards. In sum, Unit CR2 can be attributed to the early Magdalenian, probably in two stages; one assigned to the archaic Magdalenian and the other to the "Cantabrian" lower Magdalenian.

A single sample was collected in the middle of Unit CR1: OxA-38941 (Sample 3155), from Square D4, south section. Its age of 18,280-18,040 cal BP corresponds to cold oscillations in the decrease in temperature at the end of GS2b. It can also be attributed to the lower Magdalenian.

From the 1975-1979 excavations, a sample from the top of Level B (Square G4, Spit 1). $16,520-15,870$ cal BP (OxA-31707). It represents a problem of chronological inversion as it is younger compared to the date obtained for Unit CR1 (OxA-38941), which is found above level B of the 1975-1979 excavations. However, following the new fieldwork, this level has been correlated with Unit CR1, which is assigned to the Lower Magdalenian and which has been dated in consonance with that attribution by sample OxA-38941 (18,28018,040 cal BP). OxA-31707 therefore represents a chronological anomaly and should be taken with reservations as it is apparently not synchronic with the level it came from. It may be an intrusion from an upper level between CR2 and CR1 that has now disappeared. In our Bayesian model we place OxA-38941 on the top of the Solutrean sequence and OxA-31707 in the Upper Magdalenian phase.

Finally, the most recent Magdalenian date (OxA-38940) comes from the middle of Unit CR1bis in Square D6, south section (Sample 3161). The calibrated interval is 15,650-15,290 cal BP, which would date this unit in the coldest phase of GS2a, at the end of HE 1. It is indicative of an occupation in the upper Magdalenian, which is confirmed by a harpoon with a single row of barbs found by FJC in 1958 but out of context as it was in sediment dug up by the clandestine excavators. 
In our Bayesian model, the start of the Magdalenian is placed around 20,500 cal BP, between $20,640-20,310$ or $20,930-20,210$ cal BP (at $68.2 \%$ or $95.4 \%$ respectively), and it ends about 2 millennia later, around 18,000 cal BP, or between 18,230-17,900/18,270-17,400 cal BP (68.2\%/ 95.4\%). The Upper Magdalenian phase follows on; it starts at around $16800 \mathrm{cal}$ BP $(17,200$ 16,110 or $17,950-15,980$ cal BP, at $68.2 \%$ or $95.4 \%$ respectively) and based on a limited number of dates $(n=2)$ only lasts for a millennium or so.

\section{Mesolithic}

The sequence registers a large gap of several millennia, from $~ 15,500$ to 7500 (Table 3, Figure 6), before a new occupation is identified through the date obtained for a shell in one of the remnants of the shell-midden adhered to the north wall of the rock-shelter. The calibrated interval of OxA-38663 is 7680-7420 cal BP and corresponds to the Mesolithic and a time of rising temperatures after the $8.2 \mathrm{kyr}$ event, at the start of the Atlantic chronozone, in the middle of the Holocene Climate Optimum. In the new official chronostratigraphic scale, this interval is assigned to the start of the middle Holocene or Northgrippian.

\section{DISCUSSION: ${ }^{14} \mathrm{C}$ CHRONOLOGY OF COVA ROSA}

Cova Rosa contains a sequence covering the time between ca. 24,000 and $7500 \mathrm{cal}$ BP, though with a large gap between $~ 15$ th-7th millennium BP as shown in our Bayesian analysis of the data, with levels attributed to the late Upper Pleistocene (Solutrean and Magdalenian) and middle Holocene (Mesolithic). These periods are well documented and dated in the prehistory of northern Spain, for example at the caves of El Cierro (Álvarez-Fernández et al. 2018), La Riera (Straus and Clark 1986) and El Mirón (e.g., Straus and González 2003).

The Solutrean is represented at other well-dated sites in the Sella valley; for example, in Levels $\mathrm{H} 1$ and $\mathrm{H} 2$ at El Cierro (Álvarez-Fernández et al. in prep.) and Level 3 at El Buxu, with industry attributed to the upper Solutrean (Menéndez et al. 2016). In northern Spain, the evolution of this period, with an older phase known as the middle Solutrean and a more recent phase or upper Solutrean, can be followed in Sala I in the cave of Las Caldas, in Asturias (Corchón 2017a). Based on the chronological data, these two phases may be represented in Cova Rosa. From the typological point of view (Schmidt 2015), examples of points with flat retouch and laurel-leaf points may indicate the existence of either the middle or the upper phase of the Solutrean. Index fossils of the upper Solutrean, such as shouldered and concave-based points, are also present (López-Tascón et al. in prep.).

The dates obtained for Unit CR2 are coherent with the archaic or lower Magdalenian within the regional panorama. Several sites are known in the interval of ca. 20,000-19,500 cal BP, such as Level B5.1 in Coímbre B (Álvarez-Alonso and Jordá 2017) in Asturias, and Level V at El Rascaño, in Cantabria (González Echegaray and Barandiarán 1981). The upper part of Unit CR2, dated to $19,200-18,500$ cal BP can be associated with the "Cantabrian" lower Magdalenian, whose industries are well documented and dated in the Sella valley itself; for example, in Level F in El Cierro (Álvarez-Fernández et al. 2016), but also in other areas, such as in Level 2 at Altamira Cave, in Cantabria (González Echegaray 1988), where the most characteristic trait is the high percentage of backed bladelets and nucleiform endscrapers/bladelet cores, accompanied by sagaies with a square cross-section. Triangles have been documented in Levels XI-XIII in Sala I at Las Caldas (Corchón 2017b). From the subsistence viewpoint, the top part of CR2 can be related to other regional sites where 
hunting specialised in the capture of red deer, as in Levels F and $\mathrm{G}$ at El Cierro (Portero et al. 2019).

The date for CR1 (18,280-18,040 cal BP) is contemporaneous with the results for Level 3 at La Guelga, also in the Sella valley (Menéndez et al. 2004), where backed bladelets still appear in high percentages, and other sites in the northern Iberian Peninsula, like Level Lgc inf at Antoliña, in Biscay (Aguirre 2014).

If the date OxA-31707 at Cova Rosa is accepted, despite the chronological inversion, it would represent a missing middle Magdalenian level in the cave. This period is well represented in Asturias (e.g., Levels IX to VI at Las Caldas; Corchón 2017a) and in Cantabria (e.g. Lower Gallery at La Garma; Arias et al. 2011). It is known for the increasing examples of portable art on both mineral (engraved plaquettes) and animal materials (contours découpés, discs or rondelles, sculptures, etc.).

The result of the sample for CR1bis indicates the cave was occupied in the upper Magdalenian, a period that is well documented at the mouth of the River Sella. Antler harpoons with round cross-section are characteristic of this period. In addition to the harpoon recovered at Cova Rosa and others found, for example, in Level 1 at Tito Bustillo (Moure 1990), a further example has recently been described from Sector IV at Les Pedroses (Martínez Villa 2019). It is a well-known period also in the rest of northern Spain; e.g., in Level 1 at Coímbre B (Álvarez-Alonso and Jordá 2017), Level IV at La Pila, in Cantabria (Gutiérrez Saez 1998) and Level Almp/Lamc/+Slnc at Santimamiñe, in Biscay (López et al. 2020).

Deposits corresponding to the long hiatus between the upper Magdalenian and the Mesolithic have been well documented and dated at other sites in the Sella valley. They include Levels 7 and 6, attributed to the upper Magdalenian and Levels 3 and 5, attributed to the Azilian, at Los Azules I (Fernández-Tresguerres 2007); and Levels C and D, assigned to the Azilian at El Cierro (Álvarez-Fernández et al. 2020a).

The Mesolithic date for the shell-midden at Cova Rosa agrees with dates obtained in numerous similar deposits, mainly in the east of Asturias (Fano 2019). One of these is the shell-midden at the proximate site of El Cierro (Álvarez-Fernández et al. 2020a), which is assigned to the Asturian culture and dated ca. 9500/8000 cal BP.

\section{CONCLUSIONS}

Cova Rosa is one of the few sites that have been excavated over a large surface area in northern Spain. Across several field seasons in 1958, 1964, 1975-1979, and 2019, we calculated that about $23 \mathrm{~m}^{2}$ of cave fill has been excavated (Figure 2). Apart from isolated instances, the results of previous fieldwork have remained practically unpublished. Here we determine a new stratigraphic sequence that correlates with the levels identified by the previous researchers (FJC, AGF, and MHG) (Figure 3). Using radiocarbon dating we precise date the sequence using 22 samples collected in 1964, 1975-1979, and 2019. Based on the direct dates and the study of the archaeological material the cave was occupied in the different phases of the Solutrean and the Magdalenian periods, in the late Upper Pleistocene (after the Last Glacial Maximum to the start of Greenland Interstadial 1). It was also occupied in the first part of the Holocene (at the start of the middle Holocene or Northgrippian). It is interesting to note that erosion has removed most of the materials that would correspond to much of the GI 1 (late glacial period), the whole GS 1 (Younger Dryas) and all the 
early Holocene or Greenlandian. Our new data are comparable to those of similar sites in the Sella valley, e.g., El Cierro (Álvarez-Fernández et al. 2016) and Les Pedroses (Martínez Villa 2019), and in other regions of Cantabrian Spain, e.g., La Riera (Straus and Clark 1986), in Asturias; El Miron (Straus and González 2003), in Cantabria; and Antoliñako koba (Aguirre 2014), in the Basque Country). This increasing number of recently excavated and dated sites provides useful insights into the occupation of Cantabrian Spain during a period of both extreme climatic instability and cultural variability.

\section{ACKNOWLEDGMENTS}

This research was undertaken in Programa Estatal de Fomento de la Investigacion Científica y Técnica de Excelencia, of the Spanish Ministry of Economy, Industry and Competitiveness the context of the Spanish project HAR2017-82557-P. We wish to thank the University of Salamanca, Universidad Nacional de Educación a Distancia and IIIPC-University of Cantabria for their support of the project. We are equally indebted to all collaborating scientists who have worked diligently on this project. The authors would like to thank Peter Smith for the English translation of the manuscript and the anonymous reviewers and main editor whose contributions have improved this work.

\section{SUPPLEMENTARY MATERIAL}

To view supplementary material for this article, please visit https://doi.org/10.1017/RDC. 2021.18

\section{REFERENCES}

Aguirre M. 2014. Antoliñako koba (Gautegiz, Bizkaia). In: Sala R, editor. Los cazadores recolectores del Pleistoceno y del Holoceno en Iberia y el Estrecho de Gibraltar: estudio actual del conocimiento del registro arqueológico. Universidad de Burgos y Fundación Atapuerca, Burgos. p. 41-48.

Álvarez-Alonso D, Jordá Pardo JF. 2017. Secuencia estratigráfica, radiocarbono y cronoestratigrafía del registro del Pleistoceno superior de la zona B de la cueva de Coímbre (Asturias, España). In: Álvarez-Alonso D, Yravedra J, directors. La cueva de Coímbre (Peñamellera Alta, Asturias): Ocupaciones humanas en el valle del Cares durante el Paleolítico superior. Oviedo: Fundación $M^{\text {a }}$ Cristina Masaveu. p. 194-216.

Álvarez-Fernandez E, Álvarez-Alonso D, Bécares J, Carral P, Carriol R-P, Chauvin A, Cubas M, Cueto M, Domingo R, Douka K, et al. 2016. Nouvelles données sur le Magdalénien inférieur de la Région Cantabrique : le Niveau F de la grotte de El Cierro (Ribadesella, Asturies, Espagne). L'Anthropologie 120: 537-567. doi: 10.1016/j.anthro.2016.09.001.

Álvarez-Fernández E, Andrés M, Aparicio MT, Elorza M, Gabriel S, García-Ibaibarriaga N, Murelaga X, Portero R, Sensburg M, Suárez-Bilbao A, et al. 2019a. Biotic Resources in the Lower
Magdalenian at Cova Rosa (Sardeu, Asturias, Spain). Quaternary International 506:25-34.

Álvarez-Fernández E, Bécares J, Jordá Pardo JF, Aguirre-Uribesalgo A, Álvarez-Alonso D, de Andrés-Herrero M, Aparicio MT, BarreraMellado I, Carral P, Carriol R-P, et al. 2018. La cueva de El Cierro (Fresnu, Ribadesella): campañas de excavación e investigación 19771979, 2014 y 2016. Excavaciones arqueológicas en Asturias 2013-2016 (VIII). Oviedo: Consejería de Educación, Cultura y Deporte, Principado de Asturias. p. 93-106.

Álvarez-Fernández E, Bécares J, Jordá Pardo JF, Agirre-Uribesalgo A, Álvarez-Alonso D, Aparicio MT, Barrera-Mellado I, Carral P, Carriol R-P, Cubas M, et al. 2020a. Palaeoenvironmental and chronological context of human occupations at El Cierro cave (Northern Spain) during the transition from the late Upper Pleistocene to the early Holocene. Journal of Archaeological Science: Reports 29. doi: 10.1016/j.jasrep.2019.102138.

Álvarez-Fernández E, Bécares J, Jordá Pardo JF, Álvarez-Alonso D, Elorza M, GarcíaIbaibarriaga N, Jarque SM, Hernández RP, Suárez-Bilbao A, Tapia J, et al. 2019b. Back to 1964: new data on the Solutrean levels at Cova Rosa (Sardeu, Ribadesella, Asturias). In: 
Schmidt I, Cascalheira J, Bicho N, Weniger G-C, editors. Human adaptations to the Last Glacial Maximum: the Solutrean and its neighbors. Newcastle Upon Tyne: Cambridge Scholar Publishing. p. 112-132.

Álvarez-Fernández E, Bécares J, Jordá-Pardo JF, Martín-Jarque S, et al. 2020b. Cova Rosa (Sardeu, Asturias, España) durante el Magdaleniense: sesenta años de investigaciones. In: Straus LG, Langlais M, editors. Magdalenian chrono-estratigraphic correlations and cultural connections between Cantabrian Spain and Southwest France... and beyond. Société Préhistorique Française. Séances de la SPF, Mémoire 15 Paris. p. 234-250.

Álvarez-Fernández E, Jordá Pardo JF, editors. 2018. El poblamiento prehistórico en el valle del Sella. Cincuenta años del descubrimiento de la cueva de Tito Bustillo y sesenta de las primeras intervenciones del Profesor Francisco Jordá en las cuevas de El Cierro y Cova Rosa (Ribadesella, Asturias). UNED, Ediciones Universidad de Salamanca y Asociación Cultural Amigos de Ribadesella, Ribadesella.

Arias P, Álvarez-Fernández E, Cueto M, Elorza M, García-Moncó C, Güth A, Iriarte M. J, Teira LC, Zurro D. 2011. Magdalenian floors in the Lower Gallery of La Garma: a preliminary approach. In: Gaudzinski S, Jöris O, Sensburg M, Street M, Turner E, editors. Site-internal spatial organization of hunter-gatherer societies: Case studies from the European Palaeolithic and Mesolithic. Mainz: RGZM-Tagungen 12. p. 31-51.

Björck S, Walker MJC, Cwynar LC, Johnsen S, Knudsen K-L, Lowe JJ, Wohlfarth B. 1998. An event stratigraphy for the Last Termination in the north Atlantic based on the Greenland Ice Core record: a proposal by the INTIMATE group. Journal of Quaternary Science 13: 283-292.

Brock F, Higham TFG, Ditchfield P, Ramsey CB. 2010. Current pre-treatment methods for AMS radiocarbon dating at the Oxford Radiocarbon Accelerator Unit (ORAU). Radiocarbon 52:103-112.

Bronk Ramsey C. 2001. Development of the radiocarbon calibration program. Radiocarbon 43(2A):355-363.

Bronk Ramsey C. 2009a. Bayesian analysis of radiocarbon dates. Radiocarbon 51(1): 337-360.

Bronk Ramsey C. 2009b. Dealing with outliers and offsets in radiocarbon dating. Radiocarbon 51(3):1023-1045.

Corchón MS, editor. 2017a. La cueva de las Caldas (Priorio, Oviedo). Ocupaciones solutrenses, análisis espaciales y arte parietal. Universidad de Salamanca, Estudios Históricos 166, Salamanca.

Corchón MS, editor. 2017b. La cueva de las Caldas (Priorio, Oviedo). Ocupaciones magdalenienses en el valle del Nalón. Universidad de Salamanca, (Estudios Históricos 164), Salamanca.

Fano MA. 2019. The Mesolithic "Asturian" culture (North Iberia), one century on. Quaternary International 515:159-175.

Fernández-Tresguerres JA. 2007. El final del Paleolítico en los espacios cantábricos. In: Fano MA, editor. Las Sociedades del Paleolítico en la Región Cantábrica. Diputación Foral de Bizkaia, Anejo de Kobie 8, Bilbao. p. 337-402.

González Sainz, C. 1989. El Magdaleniense superiorfinal de la región cantábrica. Tantín y Universidad de Cantabria, Santander.

González Echegaray J. 1988. El Magdaleniense de Altamira. Espacio, Tiempo y Forma, Serie I, Prehistoria y Arqueología 1:165-175.

González Echegaray J, Barandiarán I, editors. 1981. El Paleolítico Superior de la cueva del Rascaño (Santander). Centro de Investigaciones y Museo de Altamira 3, Santander.

Gutiérrez Saez C. 1998. Cambios en el equipamiento instrumental entre el Paleolítico final y el Epipaleolítico: la cueva de la Pila. Cuadernos de Prehistoria de la Universidad Autónoma de Madrid 25(1):87-118.

Heaton TJ, Köhler P, Butzin M, Bard E, Reimer RW, Austin WEN, Bronk Ramsey C, Grootes PM, Hughen KA, Kromer B, et al. 2020. Marine20 - the marine radiocarbon age calibration curve (0-55,000 cal BP). Radiocarbon 62(4):779-820.

Hoyos Gómez M. 1979. El karst de Asturias en el Pleistoceno superior y Holoceno. Estudio morfológico, sedimentológico y paleoclimático [unpublished Ph.D. thesis]. Universidad Complutense de Madrid, Madrid.

Jordá Cerdá F. 1977. Historia de Asturias. Prehistoria. Vol. 1. Vitoria-Oviedo, Ayalga, Salinas.

Jordá Cerdá F, Gómez, Fuentes A. 1982. Cova Rosa A, Departamento de Prehistoria y Arqueología. Salamanca: Universidad de Salamanca.

Laplace G. 1973. Sobre la aplicación de las coordenadas cartesianas en la excavación estratigráfica. Speleon 20:139-159.

López JC, González Sainz C, Guenaga A. 2020. La cueva de Santimamiñe (Kortezubi, Bizkaia). In: Straus LG, Langlais M, editors. Magdalenian chrono-estratigraphic correlations and cultural connections between Cantabrian Spain and Southwest France.... and beyond. Société Préhistorique Française. Séances de la SPF, Mémoire 15 Paris. p. 275-294.

Martínez Villa A. 2019. Arte y ocupación prehistórica de la Cueva de Les Pedroses. Asociación Cultural de Amigos de Ribadesella, Ribadesella.

Menéndez M, García E, Quesada J. 2004. Magdaleniense inferior y territorialidad en la Cueva de La Güelga (Asturias). In: Bicho N, editor. O Paleolitico. ADECAP, Universidade do Algarve. Promotoria Monográfica 02, Faro:63-75. 
Menéndez M, Jordá J, Quesada JM, Rojo J, Saura P. 2016. La Cueva del Buxu (Cangas de Onís, Asturias) en el centenario de su descubrimiento. Excavaciones Arqueológicas en Asturias (Monografías IV). Gobierno del Principado de Asturias. Oviedo.

Mestres JS. 1995. La datació per radiocarboni i el calibratge de les dates radiocabòniques. Objectius, problemes i aplicacions. Revista d'Arqueologia de Ponent 5:260-275.

Mestres JS. 2000. La datació per radiocarboni. Una visión actual. Tribuna d'Arqueologia, 19971998:195-239.

Mestres JS. 2003. La química i la cronologia: la datació per radiocarboni. Revista de la Societat Catalana de Química 4:11-25.

Mestres JS. 2008. El temps a la Prehistòria i el seu establiment a través de la datación per radiocarboni. Cypsela 17:11-21.

Moure JA. 1990. La cueva de Tito Bustillo (Ribadesella, Asturias): el yacimiento paleolítico. Excavaciones Arqueológicas en Asturias, I. Gobierno del Principado de Asturias. Oviedo. p. 107-127.

Navarro D, Leyva F, Villa E, Granados L. 1986. Mapa Geológico de España E. 1:50.000 Hoja 31 (15-4) Ribadesella. Instituto Geológico y Minero de España, Centro de Publicaciones, Ministerio de Industria y Energía, Madrid.

Portero R, Cueto M, Jordá Pardo JF, Bécares J, Álvarez-Fernández E. 2019. The persistence of red deer (Cervus elaphus) in the human diet during the Lower Magdalenian in northern Spain: Insights from El Cierro cave (Asturias, Spain). Quaternary International 506:35-45.
Reimer PJ, Austin WEN, Bard E, Bayliss A, Blackwell PG, Ramsey CB, Butzin M, Cheng H, Edwards RL, Friedrich M, et al. 2020. The IntCal20 Northern Hemisphere radiocarbon age calibration curve (0-55 cal kBP). Radiocarbon 62(4):725-757. doi: 10.1017/RDC.2020.41.

Schmidt I. 2015. Solutrean Points of the Iberian Peninsula: tool making and using behaviour of hunter-gatherers during the Last Glacial Maximum. Oxford: BAR International Series 2778.

Soares AMM, Gutiérrez FI, González MR, Matos JMM, Cuenca D, Bailey GN. 2016. Marine radiocarbon reservoir effect in late Pleistocene and early holocene coastal waters off northern Iberia. Radiocarbon 58(4):869-883.

Straus LG. 1983. El Solutrense Vasco-cantábrico. Una Nueva Perspectiva. Ministerio de Cultura (Monografías del Centro de Investigación y Museo de Altamira 10), Madrid.

Straus LG, Clark GA. 1986. La Riera Cave, Stone Age hunther-gatherer adaptions in northern Spain. Anthropological Research Papers 36. Tempe (AZ): Arizona State University.

Straus LG, González MR. 2003. El Miron Cave and the ${ }^{14} \mathrm{C}$ chronology of Cantabrian Spain. Radiocarbon 45:41-58.

Svensson A, Andersen KK, Bigler M, Clausen HB, Dahl-Jensen D, Davies SM, Johnsen SJ, Muscheler R, Parrenin F, Rasmussen SO, et al. 2008. A 60000 year Greenland stratigraphic ice core chronology. Climate of the Past 4(1):47-57.

Utrilla P. 1981. El Magdaleniense Inferior y Medio en la costa cantábrica. Ministerio de Cultura. (Monografías del Centro de Investigación y Museo de Altamira 4), Madrid. 